Article

\title{
Assessment of Tamarindus indica Extracts for Antibacterial Activity
}

Uchechukwu U. Nwodo $^{1, *}$, Grace E. Obiiyeke ${ }^{2}$, Vincent N. Chigor ${ }^{1}$ and Anthony I. Okoh ${ }^{1}$

1 Applied and Environmental Microbiology Research Group (AEMREG), Department of Biochemistry and Microbiology, University of Fort Hare, Private Bag X1314, Alice 5700, South Africa; E-Mails: vchigor@ufh.ac.za (V.N.C.); aokoh@ufh.ac.za (A.I.O.)

2 Department of Botany, Delta State University, Abraka, 330106, Delta State, Nigeria; E-Mail: ekygee@yahoo.com

* Author to whom correspondence should be addressed; E-Mail: unwodo@ufh.ac.za or uchenwodo@gmail.com; Tel.: +27-786273279.

Received: 30 August 2011; in revised form: 19 September 2011 / Accepted: 22 September 2011 / Published: 26 September 2011

\begin{abstract}
Ethanolic and aqueous (hot and cold) extracts of the fruit pulp, stem bark and leaves of Tamarindus indica were evaluated for antibacterial activity, in vitro, against 13 Gram negative and 5 Gram positive bacterial strains using agar well diffusion and macro broth dilution techniques, simultaneously. The fruit pulp extracts exhibited a wide spectrum of activity; the cold water extract against $95.5 \%$ of the test bacterial strains; and the hot water and ethanolic extracts against $90.9 \%$ and $86.4 \%$, respectively. In contrast the cold water extract of the leaves and stem bark, each was active against $16.7 \%$; while the ethanolic extract of each was active against $75 \%$ of the test strains. The minimum inhibitory concentrations (MIC) ranged from $7.81 \mathrm{mg} / \mathrm{mL}$ against Bacillus subtilis ATCC 6051 to $31.25 \mathrm{mg} / \mathrm{mL}$ against Escherichia coli ATCC 11775; and the minimum bactericidal concentration (MBC) ranged from $125 \mathrm{mg} / \mathrm{mL}$ against Pseudomonas aeruginosa ATCC 10145 to $250 \mathrm{mg} / \mathrm{mL}$ against Bacillus subtilis ATCC 6051.
\end{abstract}

Keywords: Tamarind; Tamarindus indica; extracts; antibacterial activity 


\section{Introduction}

All through history, irrespective of culture, plants have been a dependable source of medicine [1,2]; and $70-90 \%$ of the world's rural population still depends on herbal remedies for health care [3]. Tamarindus indica L., (Tamarind), family, Leguminosae, is one such widely used medicinal plant. It is found in virtually all tropical climatic regions, from India through Africa to the Caribbean and South America and up to Southern Florida. Its uses are as varied as the cultures that use it. It is often more difficult to determine which use is more important, as food and beverage [4,5] or as folklore medicine [5,6]. In the West African sub-region, including Nigeria, it is widely used as both food and medicine. The pulp has been documented in both the British and American pharmacopoeias as anti-pyretic, antiscorbutic, laxative, carminative and remedy for biliousness and bile disorder [5-8]; and the leaves have antihelmintic and vermifuge properties, destroying intestinal parasites [6]. The work reported here was carried out to validate the medicinal use of this plant in Northern Nigerian folklore.

\section{Results and Discussion}

\subsection{Results}

Generally, the cold water extracts gave higher percentage yields (w/w) after extraction, range, 9.7\% (stem bark) to $14.4 \%$ (fruit pulp); while ethanol had the least yield, $8.8 \%$ to $9.6 \%$. Likewise the fruit pulp gave the highest yield, $9.6 \%$ to $14.4 \%$. The $\mathrm{pH}$ ranged from 2.0 for the cold water extract of the fruit pulp to 5.5 for the cold water extract of the leaves (Table 1).

Table 1. The yield and $\mathrm{pH}$ of the various crude extracts of Tamarindus indica.

\begin{tabular}{|c|c|c|}
\hline Extract & Yield (\%) & pH \\
\hline \multicolumn{3}{|c|}{ Leaves (L) } \\
\hline Cold Water (LCW) & $5.76(11.5)$ & 5.45 \\
\hline Hot Water (LHW) & $5.21(10.4)$ & 4.99 \\
\hline Ethanol (LET) & $4.38(8.8)$ & 4.71 \\
\hline \multicolumn{3}{|c|}{ Stem bark (S) } \\
\hline Cold water (SCW) & $4.85(9.7)$ & 4.81 \\
\hline Hot water (SHW) & $4.65(9.3)$ & 4.70 \\
\hline Ethanol (SET) & $4.58(9.2)$ & 4.62 \\
\hline \multicolumn{3}{|c|}{ Fruit pulp (F) } \\
\hline Cold water (FCW) & $7.21(14.4)$ & 2.00 \\
\hline Hot Water (FHW) & $6.54(13.1)$ & 2.91 \\
\hline Ethanol (FET) & $4.82(9.6)$ & 3.18 \\
\hline
\end{tabular}

Carbohydrates, reducing sugars, tannins and saponins were detected in all extracts. With the exception of the cold and hot water extracts of the leaves, flavonoids and Cyanogenic glycosides were present in all extracts. Anthroquinone was detected in cold water extract of the fruit pulp in addition to all the ethanolic extracts. Alkaloids were present in all the ethanolic extracts as well as the cold and hot water extracts of the fruit pulp. Steroles were not found in any extract and terpenes occurred only in the ethanolic extract of the fruit pulp (Table 2). 
Table 2. Phyto-chemical Constituents of Extracts of Tamarindus indica.

\begin{tabular}{c|ccccccccc}
\hline \multirow{2}{*}{$\begin{array}{c}\text { Constituents } \\
\text { tested }\end{array}$} & \multicolumn{8}{|c}{ Presence of constituent in plant Extract } \\
\cline { 2 - 10 } & \multicolumn{7}{c}{ Leaves } & \multicolumn{7}{c}{ Stem bark } & \multicolumn{3}{c}{ Fruit pulp } \\
\cline { 2 - 11 } & LCW & LHW & LET & SCW & SHW & SET & FCW & FHW & FET \\
\hline Carbohydrate & ++ & ++ & + & ++ & ++ & ++ & + & +++ & + \\
Reducing sugar & ++ & + & + & ++ & + & + & + & ++ & + \\
Tannins & + & + & ++ & + & + & + & + & + & + \\
Flavonoids & ND & ND & + & + & + & +++ & ++ & + & +++ \\
Anthroquinone & ND & ND & + & ND & ND & ++ & + & ND & ++ \\
Saponins & + & + & ++ & ++ & ++ & +++ & +++ & +++ & +++ \\
Alkaloids & ND & ND & + & ND & ND & +++ & ++ & +++ & +++ \\
Cyanogenic & ND & ND & + & + & + & ++ & ++ & ++ & ++ \\
glycosides & & & & & & & & & \\
Terpenes & ND & ND & ND & ND & ND & ND & ND & ND & + \\
Sterols & ND & ND & ND & ND & ND & ND & ND & ND & ND \\
\hline
\end{tabular}

Present in high mount $(+++)$; present in moderate amount $(++)$; present in low amount $(+)$; not detected (ND); LCW = leaves cold water extract, LHW = leaves hot water extract, LET = leaves ethanol extract; SCW = stem cold water extract, SHW = stem hot water extract, $\mathrm{SET}=$ stem ethanol extract; FCW = fruit pulp cold water extract, FHW = fruit pulp hot water extract, $\mathrm{FET}=$ fruit pulp ethanol extract.

The cold water extract of the fruit pulp was active against all $(100 \%)$ of the non diarrhea-genic bacterial strains tested achieving inhibition zone diameters (IZDs) ranging from $18 \pm 0.0 \mathrm{~mm}$ to $24.5 \pm 0.71 \mathrm{~mm}$ and minimum bactericidal concentration (MBC) of $125 \mathrm{mg} / \mathrm{mL}$ (Tables 3 and 4 ); but both the hot water and ethanolic extracts were active against $6(85.71 \%)$ each. Similarly, both ethanolic extracts of the leaves and stem bark showed activity against 5 (71.43\%) of the non diarrheagenic bacterial strains each whilst the cold water extract of leaves, stem bark and hot water extract of the stem bark each showed activity against $28.57 \%$, respectively. The fruit pulp extracts were active against all five Gram positive test bacterial strains with MBC values of $125-250 \mathrm{mg} / \mathrm{mL}$; but the ethanolic extracts of the stem bark (SET) and leaves (LET) showed activity against 80\% each (Table 3). Seven (7) local clinical isolates of E. coli from infantile diarrhea (numbered 1-7) and 3 of Pseudomonas aeruginosa (numbered 1 and 2, respectively) including one found to be multiple drug resistant (coded MDR) were specifically tested with SET and all the fruit pulp extracts and the results are shown in Table 5. With the exception of one isolate, E. coli 2, which showed no susceptibility to all the extracts tested and E. coli 4, which was not affected by FET, the local isolates including the multiple drug resistant $P$. aeruginosa were susceptible with IZD range of $10.50 \pm 0.00 \mathrm{~mm}$ to $28.00 \pm 0.00 \mathrm{~mm}$. Figures 1 and 2 shows the dose response curves of $T$. indica fruit pulp extract tested in vitro against representatives of Gram negative and Gram positive bacterial strains, respectively. The result showed that the IZD increased directly with the concentrations of the extracts used irrespective of the solvent used for extraction. 
Table 3. Antibacterial activity of the various parts of Tamarindus indica against test bacterial isolates.

\begin{tabular}{|c|c|c|c|c|c|c|c|c|c|c|}
\hline \multirow{3}{*}{ Bacterial Strain } & \multicolumn{10}{|c|}{ Mean Inhibition Zone Diameter $(250 \mathrm{mg} / \mathrm{mL})$} \\
\hline & \multicolumn{3}{|c|}{ Leaves } & \multicolumn{3}{|c|}{ Stem bark } & \multicolumn{3}{|c|}{ Fruit pulp } & \multirow{2}{*}{$\begin{array}{c}\text { Control } \\
\text { Ciproflox }\end{array}$} \\
\hline & $\mathbf{L C W}$ & LHW & LET & SCW & SHW & SET & FCW & FHW & FET & \\
\hline E. coli (clin) & $10.50 \pm 0.25$ & 0.00 & $8.0 \pm 0.25$ & $8.0 \pm 0.0$ & $13.0 \pm 0.0$ & $20.0 \pm 1.41$ & $20.0 \pm 0.0$ & $23.0 \pm 0.0$ & $18.0 \pm 0.0$ & $24.0 \pm 0.45$ \\
\hline E. coli ATCC 11775 & 0.00 & 0.00 & $10.0 \pm 0.75$ & $7.0 \pm 0.0$ & $7.0 \pm 0.0$ & $10.0 \pm 0.0$ & $20.0 \pm 0.0$ & $19.0 \pm 0.0$ & $10.0 \pm 0.0$ & $31.85 \pm 0.25$ \\
\hline Salmonella typhi (clin) & 0.00 & 0.00 & 0.00 & 0.00 & 0.00 & 0.00 & $20.5 \pm 0.71$ & $20.0 \pm 0.0$ & $12.0 \pm 0.0$ & $19.0 \pm 0.25$ \\
\hline Salmonella kintambo SSRL 113 & 0.00 & 0.00 & 0.00 & 0.00 & 0.00 & 0.00 & $19.0 \pm 0.0$ & $19.0 \pm 0.0$ & $21.0 \pm 0.0$ & $24.8 \pm 0.50$ \\
\hline Staph. aureus (clin) & 0.00 & 0.00 & $8.50 \pm 0.25$ & 0.00 & 0.00 & $19.5 \pm 0.71$ & $24.5 \pm 0.71$ & $12.0 \pm 0.0$ & $23.0 \pm 0.0$ & $25.85 \pm 0.25$ \\
\hline Staph. aureus ATCC 12600 & 0.00 & 0.00 & 0.00 & 0.00 & 0.00 & 0.00 & $18.0 \pm 0.0$ & $19.0 \pm 0.0$ & $14.0 \pm 0.0$ & $23.25 \pm 0.25$ \\
\hline Ps. aeruginosa (clin) & 0.00 & 0.00 & $11.50 \pm 0.75$ & 0.00 & 0.00 & $23.0 \pm 0.0$ & $21.5 \pm 0.71$ & $17.0 \pm 0.0$ & $21.5 \pm 0.71$ & $23.25 \pm 0.50$ \\
\hline Ps. aeruginosa ATCC 10145 & $9.5 \pm 0.25$ & 0.00 & $11.50 \pm 0.75$ & 0.00 & 0.00 & $19.0 \pm 0.0$ & $21.5 \pm 0.71$ & $21.0 \pm 0.0$ & $23.0 \pm 0.41$ & $26.0 \pm 0.71$ \\
\hline B. subtilis ATCC 6051 & 0.00 & 0.00 & $10.50 \pm 0.25$ & 0.00 & 0.00 & $16.0 \pm 0.0$ & $20.5 \pm 0.71$ & $24.0 \pm 0.0$ & $18.5 \pm 4.95$ & $31.0 \pm 0.25$ \\
\hline Proteus mirabilis (clin) & 0.00 & 0.00 & $10.50 \pm 0.25$ & 0.00 & 0.00 & $16.0 \pm 1.41$ & $20.5 \pm 0.71$ & 0.00 & 0.00 & $22.5 \pm 0.71$ \\
\hline B. cereus NRRL 14724 & 0.00 & 0.00 & $9.5 \pm 0.69$ & 0.00 & 0.00 & $18.0 \pm 0.0$ & $21.5 \pm 0.71$ & $17.0 \pm 0.0$ & $21.50 \pm 0.71$ & $24.25 \pm 0.50$ \\
\hline B. cereus NRRL 14725 & 0.00 & 0.00 & $12.50 \pm 0.25$ & 0.00 & 0.00 & $10.5 \pm 0.71$ & $18.5 \pm 0.71$ & $15.0 \pm 0.0$ & $20.50 \pm 0.71$ & $26.0 \pm 0.71$ \\
\hline
\end{tabular}

Table 4. The minimum inhibitory concentration (MIC), minimum bactericidal concentration and MIC-minimum bactericidal concentration $(\mathrm{MBC})$ index on the test isolates.

\begin{tabular}{|c|c|c|c|c|c|c|c|c|c|c|c|c|}
\hline \multirow[b]{2}{*}{ Bacterial Strain } & \multicolumn{3}{|c|}{ SET } & \multicolumn{3}{|c|}{ FCW } & \multicolumn{3}{|c|}{ FHW } & \multicolumn{3}{|c|}{ FET } \\
\hline & MIC & MBC & $\begin{array}{c}\text { MBC-MIC } \\
\text { INDEX } \\
\end{array}$ & MIC & MBC & $\begin{array}{c}\text { MBC-MIC } \\
\text { INDEX } \\
\end{array}$ & MIC & MBC & $\begin{array}{c}\text { MBC-MIC } \\
\text { INDEX } \\
\end{array}$ & MIC & MBC & $\begin{array}{c}\text { MBC-MIC } \\
\text { INDEX } \\
\end{array}$ \\
\hline E. coli & 15.63 & 125 & 0.125 & 31.25 & 125 & 0.25 & 31.25 & 125 & 0.25 & 62.50 & 125 & 0.50 \\
\hline E. coli ATCC 11775 & 31.25 & 125 & 0.25 & 31.25 & 125 & 0.25 & 62.50 & 125 & 0.50 & 125 & 125 & 1 \\
\hline Salmonella typhi & 0 & ND & ND & 0 & ND & ND & 62.50 & 125 & 0.50 & 125 & 125 & 1 \\
\hline Salmonella kintambo SSRL 113 & 0 & ND & ND & 31.25 & 0 & ND & 31.25 & 125 & 0.25 & 62.50 & 125 & 0.50 \\
\hline
\end{tabular}


Table 4. Cont.

\begin{tabular}{|c|c|c|c|c|c|c|c|c|c|c|c|c|}
\hline \multirow[b]{2}{*}{ Bacterial Strain } & \multicolumn{3}{|c|}{ SET } & \multicolumn{3}{|c|}{ FCW } & \multicolumn{3}{|c|}{ FHW } & \multicolumn{3}{|c|}{ FET } \\
\hline & MIC & MBC & $\begin{array}{c}\text { MBC-MIC } \\
\text { INDEX }\end{array}$ & MIC & MBC & $\begin{array}{c}\text { MBC-MIC } \\
\text { INDEX }\end{array}$ & MIC & MBC & $\begin{array}{c}\text { MBC-MIC } \\
\text { INDEX }\end{array}$ & MIC & MBC & $\begin{array}{c}\text { MBC-MIC } \\
\text { INDEX }\end{array}$ \\
\hline Staph. aureus & 15.63 & 125 & 0.125 & 31.25 & 125 & 0.25 & 125 & 125 & 1 & 62.50 & 125 & 0.50 \\
\hline Staph. aureus ATCC 12600 & 0 & ND & ND & 31.25 & 125 & 0.25 & 62.50 & 125 & 0.50 & 62.50 & 125 & 0.50 \\
\hline Ps. aeruginosa & 15.63 & 250 & 0.125 & 7.81 & 250 & 0.0312 & 31.25 & 125 & 0.25 & 62.50 & 125 & 0.50 \\
\hline Ps. aeruginosa ATCC 10145 & 7.81 & 125 & 0.063 & 31.25 & 125 & 0.25 & 31.25 & 125 & 0.25 & 62.50 & 125 & 0.50 \\
\hline B. subtilis ATCC 6051 & 7.81 & 250 & 0.0312 & 62.50 & 250 & 0.25 & 31.25 & 125 & 0.25 & 62.50 & 125 & 0.50 \\
\hline Proteus mirabilis & 7.81 & 0 & ND & 62.50 & 0 & ND & 0 & 0 & ND & 0 & 0 & ND \\
\hline B. cereus NRRL 14724 & 15.63 & 125 & 0.125 & 62.50 & 125 & 0.50 & 62.50 & 125 & 0.50 & 62.50 & 250 & 0.25 \\
\hline B. cereus NRRL 14725 & 62.50 & 125 & 0.50 & 62.50 & 125 & 0.50 & 62.50 & 250 & 0.25 & 62.50 & 125 & 0.50 \\
\hline
\end{tabular}

$\mathrm{ND}=$ Not determined; $0=$ absence of activity.

Table 5. Effects of Tamarindus indica crude extracts On E. coli isolates from infantile diarrhea, Pseudomonas aeruginosa isolates and its multi-drug resistant strain (Pseudomonas aeruginosa MDR).

\begin{tabular}{c|ccccc}
\hline \multirow{2}{*}{ Bacterial Strain } & \multicolumn{4}{|c}{ Mean Inhibition Zone Diameter (250 mg/mL) } \\
\cline { 2 - 5 } & Stem bark & \multicolumn{3}{c}{ Fruit pulp } & Control \\
\cline { 2 - 5 } & SET & FCW & FHW & FET & Ciproflox (20 $\boldsymbol{\mu g} / \mathbf{m L )}$ \\
\hline E. coli 1 & $20.0 \pm 0.0$ & $21.0 \pm 0.0$ & $19.0 \pm 0.0$ & $20.50 \pm 0.71$ & $23.25 \pm 0.25$ \\
E. coli 2 & 0.00 & 0.00 & 0.00 & 0.00 & $11.0 \pm 0.50$ \\
E. coli 3 & $10.50 \pm 0.0$ & $25.0 \pm 0.0$ & $12.0 \pm 0.0$ & $24.50 \pm 0.71$ & $13.50 \pm 0.50$ \\
E. coli 4 & $13.50 \pm 0.71$ & $23.0 \pm 0.0$ & $22.0 \pm 0.0$ & 0.00 & $23.85 \pm 0.45$ \\
E. coli 5 & $17.50 \pm 0.71$ & $26.0 \pm 0.0$ & $23.0 \pm 0.0$ & $27.0 \pm 0.0$ & $25.85 \pm 0.25$ \\
E. coli 6 & $21.50 \pm 0.71$ & $17.0 \pm 0.0$ & $19.50 \pm 0.71$ & $18.0 \pm 0.0$ & $28.0 \pm 0.40$ \\
E. coli 7 & $16.50 \pm 0.71$ & $28.0 \pm 0.0$ & $19.50 \pm 0.71$ & $14.0 \pm 0.0$ & $19.50 \pm 0.0$ \\
Ps. aeruginosa 1 & $20.50 \pm 0.71$ & $24.0 \pm 0.0$ & $20.0 \pm 0.0$ & $18.0 \pm 1.41$ & $24.85 \pm 0.71$ \\
Ps. aeruginosa 2 & $17.50 \pm 0.71$ & $19.0 \pm 0.0$ & $19.0 \pm 0.0$ & $26.0 \pm 0.0$ & $26.0 \pm 0.45$ \\
Ps. aeruginosa (MDR) & $19.0 \pm 0.0$ & $21.0 \pm 0.71$ & $14.0 \pm 0.0$ & $19.0 \pm 0.0$ & $17.50 \pm 0.60$ \\
\hline
\end{tabular}


Figure 1. Concentration dependent assay of $T$. indica fruit pulp on Ps. aeruginosa ATCC 10145.

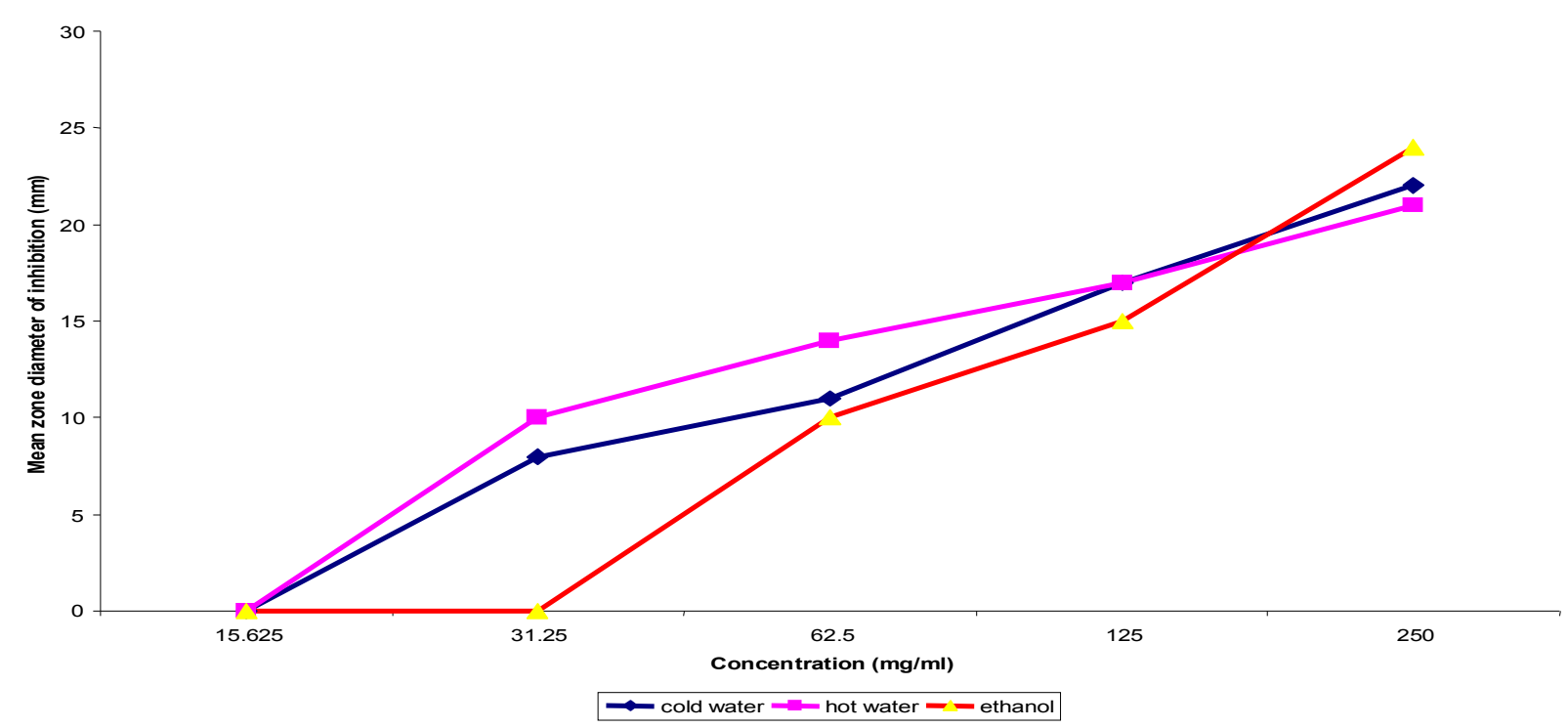

Figure 2. Concentration dependent assay of T. indica fruit pulp on Bacillus subtilis ATCC 6051.

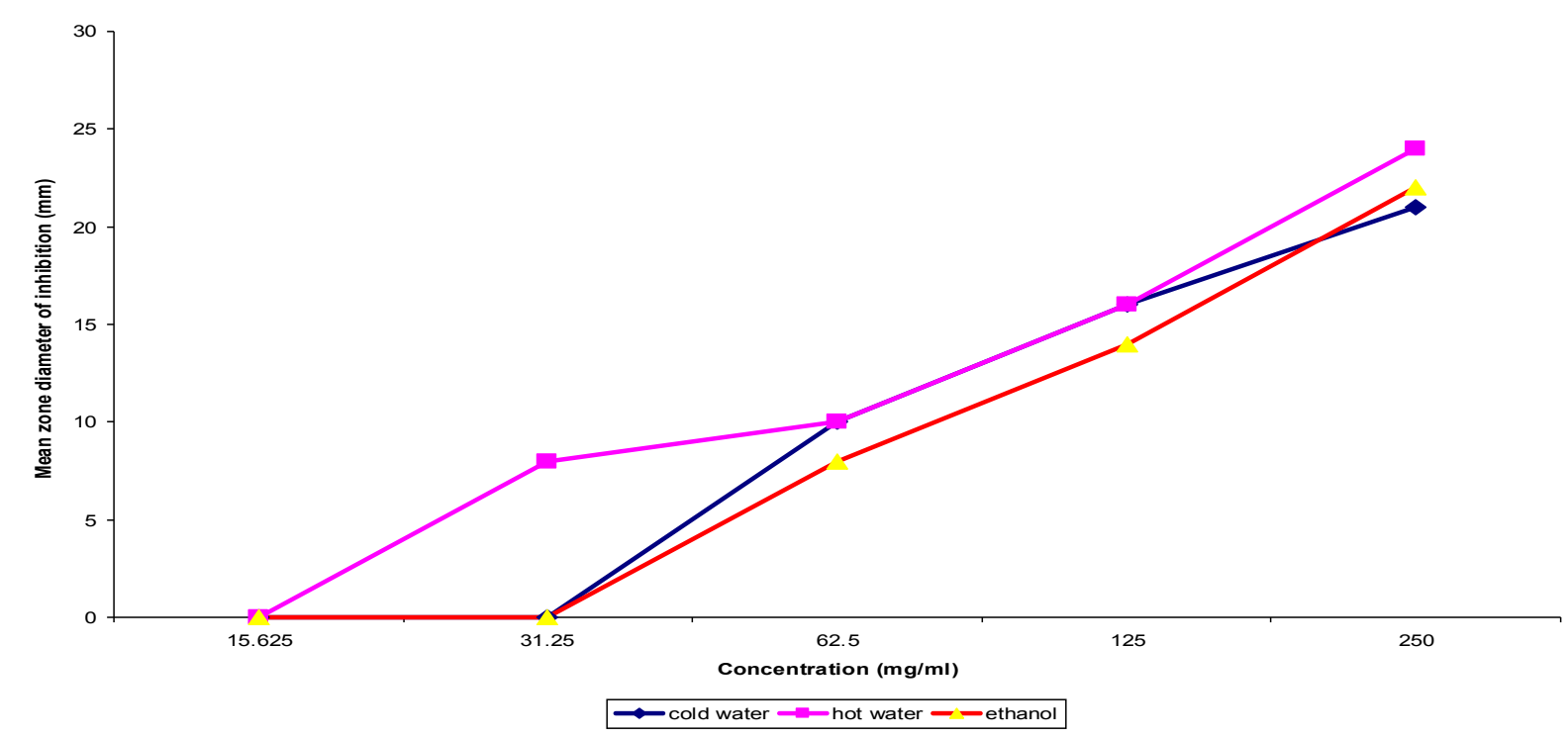

\subsection{Discussion}

In all cases the highest yield was obtained with cold water extraction, followed by hot water and ethanol the least signifying that most of the components extracted were water soluble. Relatively, more yield was obtained from the fruit pulp with every extraction solvent than from leaves or stem bark showing that more components were contained in the fruits. It is interesting that the fruit which is frequently consumed as food or beverage contained large quantities of water soluble constituents, some of which were shown in this work to have antibacterial activity. What needs to be ascertained is whether the antibacterial activity would remain in vivo after they have been acted upon by the digestive enzymes. The yield obtained may be limited by the method of extraction, maceration, which 
has been noted to be inferior to Soxhlet extraction technique [9]. The low $\mathrm{pH}$ of the extracts may reflect the presence of high levels of oxalic acid, ascorbic acid and, particularly, tartaric acid which is an unusual plant acid [5].

The phytochemical constituents detected, including flavonoids, alkaloids, tannins, cyanogenic glycosides and anthroquinones. These may have accounted for antibacterial activity [10,11]. These phytochemicals and some other aromatic secondary metabolites have been suggested to serve as natural agents that protect plants agents against microbial pathogens and insect predators [12]. Their distribution varied more with plant part (leaves, stem bark and fruit pulp) than with solvent of extraction in contrast to the observation of Doughari [13]. The uneven distribution of these constituents in plant parts reflects the natural functions of these parts as manufacturing organs (the leaves), storage organs (the fruit) or as avenues of excretion of wastes (stem bark). This may explain why there was concentration of the antibacterial activity in the fruit pulp and the stem bark rather than the leaves. For the leaves and stem bark, antibacterial activity was found almost exclusively in the ethanol extracts, implying either that the active principles were principally alcohol soluble or that they were stabilized by the alcohol. However, considering that similar aqueous extracts of the fruit pulp were even more active than the ethanolic extracts, it is likely that the differences in activity observed between the aqueous and ethanolic extracts of the leaves reflect differences in the types of compounds extracted. Demonstration of antibacterial activity against both Gram negative and Gram positive bacteria signify a broad spectrum of activity by the extract tested; but it is not certain that this may be interpreted to mean broad spectrum of activity for the specific active principle(s) contained in the extract since partial purification experiments have shown that a crude extract contains several components some of which may interact additively or synergistically to produce a broad spectrum effect. The scope of this work did not permit investigation into the component(s) containing the active compounds. Water and alcohol are the most common media for preparation of herbal concoctions by the herbalists; and extracts prepared with the same solvents in this work showed remarkable antibacterial activity, thus authenticating the medicinal value of these in folklore practices. The dose response effect in vitro shows that the IZD could be used to estimate the level of activity of each extract. Acidity as a mechanism of the antibacterial effect of each extract is ruled out because the in vitro medium for bacterial culture is buffered $(\mathrm{pH} 7.3 \pm 0.1)$ and, therefore, the extracts were active at $\mathrm{pH}$ other than the low value determined for each and this concurs with the findings of Doughari [13].

\section{Experimental Section}

\subsection{Plant Materials}

The fruits, leaves and stem bark of $T$. indica were obtained from Sokoto South Local Government Area, Sokoto State of Nigeria. The plant was identified taxonomically and voucher specimen deposited at the Herbarium of the Department of Botany, University of Nigeria, Nsukka.

\subsection{Preparation of Plant Extract}

Fresh leaves and stem bark of Tamarindus indica were rinsed thoroughly in running tap water, chopped to tiny pieces and air dried at room temperature for a period of 14 days; and subsequently 
pulverised with a mechanical grinder. The flesh or pulp covering the seeds was also removed and dried as above. Approximately $50.0 \mathrm{~g}$ of ground leaves, stem bark and fruit pulp were each macerated in $200 \mathrm{~mL}$ of cold water and absolute ethanol (BDH) for a period of $24 \mathrm{~h}$ at room temperature. The hot water extraction of each of the three plant parts was as described by Okoli et al. [14]. Each preparation was filtered through a Whatman No. 1 filter paper and filtrate evaporated to dryness in a steady air current after which all extracts were stored in a sterile container and stored at room temperature.

\subsection{Phytochemical Analysis}

All the extracts obtained were screened for the presence of alkaloids, saponins, tannins, anthraquinones, glycosides, flavonoids, reducing sugar, carbohydrates and sterols using the methods of Trease and Evans [15] and Harbone [9] and are as follows;

\subsubsection{Test for Carbohydrates}

Few drops of Molisch's reagent were added to an aqueous solution of each extract followed by vigorous shaking. Thereafter, $1.0 \mathrm{~mL}$ of conc. $\mathrm{H}_{2} \mathrm{SO}_{4}$ was added carefully by sliding down the walls of the tube gently to form two layers. The solution was examined for the appearance of brown ring separating the solution into two layers.

\subsubsection{Test for Reducing Sugar}

To $1.0 \mathrm{~mL}$ of aqueous solution of each extract was added $3.0 \mathrm{~mL}$ of a mixture of equal volumes of Fehling's solutions I and II and boiled in a water bath at about $40{ }^{\circ} \mathrm{C}$ for $2 \mathrm{~min}$. A brick red color at the bottom of the test tube was an indication of the presence of reducing sugar.

\subsubsection{Test for Glycosides}

Tests for glycosides were performed as follows:

(i) To $0.1 \mathrm{~g}$ of each extract in a test tube was added $5.0 \mathrm{~mL}$ of water and the mixture heated in a water bath at $100{ }^{\circ} \mathrm{C}$ for $2 \mathrm{~min}$. The mixture was filtered through a Whatman No. 1 filter paper. A mixture of Fehling's solutions I and II were added to the filtrate until it became alkaline: followed by heating for $2 \mathrm{~min}$;

(ii) The above procedure was repeated, except that $5.0 \mathrm{~mL}$ of dilute sulphuric acid was added to $0.1 \mathrm{~g}$ of the extract instead of water: and the quantity of precipitate formed was noted;

(iii) About $0.1 \mathrm{~g}$ of each extract was put into a stoppered conical flash in which was suspended a strip of sodium picrate paper. The flask was warmed gently for about an hour at $37{ }^{\circ} \mathrm{C}$ and allowed to stand. The test paper was examined for any change in color.

\subsubsection{Test for Tannins}

Approximately $0.1 \mathrm{~g}$ of each extract was added to $2 \mathrm{~mL}$ of distilled water and boiled gently for 2 min. It was then filtered while hot, and allowed to cool. Ferric chloride solution (5\%) was added drop-wise and the experiment observed for color change. 


\subsubsection{Test for Saponins}

Presence of saponins was determined by their frothing property as well as capacity to form emulsion with oils.

(i) For the frothing test, about $5 \mathrm{mg}$ of extract was shaken vigorously with and examined for frothing;

(ii) For the emulsification test, 2 drops of olive oil was added to $5.0 \mathrm{~mL}$ of aqueous solution of the extract in a test, shaken vigorously and observed for formation of an emulsion. The control was without extract but water and olive oil.

\subsubsection{Test for Flavonoids}

A $5.0 \mathrm{~g}$ weight of the extract was detanned with acetone; the residue was extracted in warm water after evaporating the acetone in a water bath. The mixture was filtered and the filtrate used for the following tests:

(i) Lead Acetate Test: To $2.0 \mathrm{~mL}$ of the detanned aqueous solution was added $10 \%$ Lead acetate solution; a colored precipitate indicates the presence of flavonoids;

(ii) Ferric Chloride Test: A $2.0 \mathrm{~mL}$ volume of detanned aqueous suspension of extract was diluted with distilled water in a ratio of $1: 4$ and a few drops of $10 \%$ ferric chloride solution added. A green or blue solution indicates the presence of flavonoids.

\subsubsection{Test for Anthroquinones}

Approximately $0.1 \mathrm{~g}$ of the extract was mixed with $5.0 \mathrm{~mL}$ of chloroform and agitated for $5.0 \mathrm{~min}$. The solution was filtered and equal volume of ammonia was added to the filtrate and agitated again. A brick red color in the upper aqueous layer indicates the presence of free anthroquinones.

\subsubsection{Test for Terpenes and Sterols}

A $1.0 \mathrm{~g}$ weight of the extract was mixed with $5.0 \mathrm{~mL}$ of $95 \%$ ethanol and then filtered. The filtrate was evaporated to dryness and the residue re-dissolved in $5.0 \mathrm{~mL}$ of anhydrous chloroform and then filtered. The latter filtrate was divided into two portions for the following tests:

(i) Liebermann-Burchard Test: The first portion was mixed with $1 \mathrm{~mL}$ of acetic anhydride followed by the addition of $1.0 \mathrm{~mL}$ of concentrated Sulfuric acid gently down the side of the test tube to form a layer underneath. The formation of a reddish violet color at the junction of the two liquids and a green color in the chloroform layer would indicate the presence of terpenes;

(ii) Salowski's Test: To the second portion of the solution was added $2.0 \mathrm{~mL}$ of concentrated Sulfuric acid carefully down the side of the tube so that the sulfuric acid formed a layer. A reddish brown color at the interface would indicate the presence sterols. 


\subsection{Test Bacterial Strains}

Clinical and type cultures were used for the studies, the clinical strains include Staphylococcus aureus from a case of non-gonococcal urethritis, 7 strains of Escherichia coli from diarrheal stools of infants and 3 antibiotic resistant strains of Pseudomonas aeruginosa. The type cultures are 2 strains of Bacillus cereus (NRRL 14724 and NRRL 14725) obtained from the Department of Microbiology, University of Nigeria, Nsukka; Pseudomonas aeruginosa (ATCC 10145), E. coli (ATCC 11775), B. subtilis (ATCC 6051), and Staph. aureus (ATCC 12600) obtained from Bioresources Development and Conservation Project (BDCP), Nsukka; and Salmonella kintambo (SSRL 113) provided by the Department of Veterinary Microbiology and Pathology, University of Nigeria, Nsukka. Each test bacterial strain was purified by re-isolating three successive times on Mueller Hinton agar (Oxoid) and identity reaffirmed by standard bacteriological techniques [16]. Stock cultures were maintained in nutrient agar slants at $4{ }^{\circ} \mathrm{C}$.

\subsection{Screening Extracts for Antibacterial Activity}

The extracts were screened for antibacterial activity using the agar well diffusion technique [17]. MacFarland nephelometry standardized inoculums of the test bacterial strain was adjusted to $1.0 \times 10^{6} \mathrm{CFU} / \mathrm{mL}$ (Gram-positive bacteria) or $5 \times 10^{5} \mathrm{CFU} / \mathrm{mL}$ (Gram-negative bacteria), [18]. A $100 \mu \mathrm{L}$ volume of the bacterial suspension was spread over Muller Hinton agar (MHA) medium at room temperature before boring $6.0 \mathrm{~mm}$ (diameter) wells in the agar using a sterile cork borer. A $100 \mu \mathrm{L}$ volume of extract, reconstituted in sterile distilled water to a concentration of $250 \mathrm{mg} / \mathrm{mL}$, was introduced in triplicate wells into the MHA cultures. The plates were allowed to stand for about $1 \mathrm{~h}$ to allow diffusion to take place and then incubated at $37^{\circ} \mathrm{C}$ for $24 \mathrm{~h}$. The inhibition zone diameter was measures to the nearest $\mathrm{mm}$.

\subsection{Determination of Minimum Inhibitory Concentration (MIC) and Minimal Bactericidal} Concentration $(M B C)$ of Extracts

The Minimum Inhibitory Concentration (MIC) for each extract and test organism was determined by agar well diffusion method and by the macro-broth dilution technique [18]. A $125 \mathrm{mg} / \mathrm{mL}$ concentration of the reconstituted extract was serially diluted in two fold, down to $3.91 \mathrm{mg} / \mathrm{mL}$. A $100 \mu \mathrm{L}$ volume of each dilution was introduced into duplicate wells in the MHA plates pre-inoculated with test bacterial strain; and incubated at $37{ }^{\circ} \mathrm{C}$ for $24 \mathrm{~h}$. The MIC was taken as the lowest concentration of the extract showing measurable inhibition zone.

For the macro-broth dilution technique, a $100 \mu \mathrm{L}$ volume of each dilution of the extract was introduced into duplicate tubes of $2.0 \mathrm{~mL}$ Mueller Hinton broth (MHB) seeded with $100 \mu \mathrm{L}$ of the standardized suspension of the test bacterial strain. Incubation was at $37{ }^{\circ} \mathrm{C}$ for $24 \mathrm{~h}$; and MIC was taken as the lowest concentration of the extract that made the culture show no visible growth.

The Minimum Bactericidal Concentration (MBC) was determined using a modified agar well diffusion technique [18]. A $2 \mathrm{~mm}$ diameter agar disc cut out from the inhibition zone of the last three consecutive wells in each dilution showing inhibition was inoculated into a fresh sterile nutrient broth medium. The broth cultures were incubated at $37{ }^{\circ} \mathrm{C}$ for $24 \mathrm{~h}$ after which $100 \mu \mathrm{L}$ was spread over a 
fresh sterile MHA. The MHA culture was in turn incubated at $37{ }^{\circ} \mathrm{C}$ for $24 \mathrm{~h}$ and the least concentration of the extract showing no growth was taken as the MBC. An MBC which coincided with or was next to the MIC value was considered bactericidal while those that differed markedly were considered bacteristatic [19].

\section{Conclusions}

Tamarindus indica is a medicinal herb that could be considered for integration into orthodox healthcare given that it is also commonly consumed as food or beverage and, therefore, generally regarded as safe (gras). In addition, the folkloric use of $T$. indica in the treatment of various ailments and enteric disturbances have been shown to hold true, empirically, in this research as high potency against pathogenic bacteria was obtained. The antibacterial activity exhibited by the ethanolic extract of the stem bark of $T$. indica was significant in various respects; but, the solvent of extraction and the plant part extracted was important in the activity shown by the plant. However, the fruit extracts showed better activity than the stem bark extracts which is the part used by herbal practitioners. Furthermore, the bacterial strains used for this work were those involved in enteric disturbances, food borne diseases and sexually transmitted infections which are amongst the most common diseases of concern in the tropics. Thus, this justifies the use of this herb in traditional practices for the treatment of ailments caused by these organisms and more.

\section{Acknowledgments}

The authors are grateful to the Govan Mbeki Research and Development Centre (GMRDC) of the University of Fort Hare, Alice, South Africa, for the facilities used in the preparation of the manuscript.

\section{References}

1. Stockwell, C. Nature's Pharmacy; Century Hutchinson Ltd.: London, UK, 1988.

2. Thomson, W.A.R. Medicines from the Earth; McGraw-Hill Book Co.: Maidenhead, UK, 1978.

3. Lai, P.K.; Roy, J. Antimicrobial and chemopreventive properties of herbs and spices. Curr. Med. Chem. 2004, 11, 1451-1460.

4. Anon, B. The Useful Plants of India; Publications \& Information Directorate, CSIR: New Delhi, India, 1986.

5. Morton, J. Tamarind. In Fruits of Warm Climates; Creative Resources Systems, Inc.: Santa Ana, CA, USA, 1987; pp. 115-121.

6. Pamploma-Roger, G.D. Encyclopaedia of Medicinal Plants; Education and Health Library: Madrid, Spain, 1999; Volume 2, p. 536.

7. Iwu, I.M. Handbook of African Medicinal Plants; CRC Press: Boca Raton, FL, USA, 1993.

8. Raimondi, L.; Lodovici, M.; Guglielmi, F.; Banchelli, G.; Ciuffi, M.; Boldrini, E.; Pirisino, R. The polysaccharide from Tamarindus indica (TS-polysaccharide) protects cultured corneal-derived cells (SIRC cells) from ultraviolet rays. J. Pharm. Pharmacol. 2003, 55, 333-338.

9. Harbone, J.B. Phytochemical Methods: A Guide in Modern Techniques of Plant Analysis; Chapman and Hall Ltd.: London, UK, 1998; pp. 221-232. 
10. Watt, J.M.; Breyer-Brandwijk, M.G. Medicinal and Poisonous Plants of Southern and Eastern Africa; E. \& S. Livingstone: Edinburgh, UK, 1967.

11. Leven, M.D.; vanden-Berghe, D.A.; Marten, T.; Villentmick, A.; Lomweas, E.C. Screening higher plants for biological activity. Planta Med. 1979, 36, 311-312.

12. Marjorie, M.C. Plant products as antimicrobial agents. Clin. Microbiol. Rev. 1999, 12, 564-582.

13. Doughari, J.H. Antimicrobial Activity of Tamarindus indica Linn. Trop. J. Pharm. Res. 2006, 5, 597-603.

14. Okoli, A.S.; Okeke, M.I.; Iroegbu, C.U.; Ebo, P.O. Antibacterial activity of Harungana madagasceriensis leaf extracts. Phytother. Res. 2000, 6, 24-26.

15. Trease, G.E.; Evans, W.C. Phytochemistry: Introduction and General Methods. In Pharmacognosy, 11th ed.; Bailliere Tindall: London, UK, 1978; pp. 227-247.

16. Cheesbrough, M. Medical Laboratory Manual for Tropical Countries, Volume II Microbiology; Linacre House, Jordan Hill: Oxford, UK, 1984; Volume 11.

17. Okeke, M.I.; Iroegbu, C.U.; Eze, E.N.; Okoli, A.S.; Esimone, C.O. Evaluation of extracts of the root of Landolphia owerrience for antibacterial activity. J. Ethnopharmacol. 2001, 78, 119-127.

18. National Committee for Clinical Laboratory Standards (NCCLS). Methods for Dilution in Antimicrobial Susceptibility Tests: Approved Standard; NCCLS: Vilanova, PA, USA, 1993; NCCLS M2-A5.

19. National Committee for Clinical Laboratory Standards (NCCLS). Methods for Determining Bactericidal Activity of Antimicrobial Agents: Tentative Guideline; NCCLS: Villanova, PA, USA, 1992; NCCLS M26-T.

(C) 2011 by the authors; licensee MDPI, Basel, Switzerland. This article is an open access article distributed under the terms and conditions of the Creative Commons Attribution license (http://creativecommons.org/licenses/by/3.0/). 